\title{
Capturing the Economic Value of Biological Control in Western Tree Fruit
}

\section{R. Karina Gallardo ${ }^{1}$, Jay F. Brunner ${ }^{2}$ and Steve Castagnoli ${ }^{3}$}

${ }^{1}$ School of Economic Sciences, Puyallup Research and Extension Center, and the Center for Precision and Automated Agricultural Systems, Washington State University, 2606 W. Pioneer, Puyallup, WA, USA. karina_gallardo@wsu.edu

${ }^{2}$ Tree Fruit Research and Extension Center, Washington State University, $1100 \mathrm{~N}$.

Western Ave. Wenatchee, WA, USA. jfb@wsu.edu

${ }^{3}$ Department of Horticulture, Mid-Columbia Agricultural Research and Extension

Center, Oregon State University, 3005 Experiment Station Drive, Hood River, OR, USA. steve.castagnoli@oregonstate.edu 


\begin{abstract}
The economic value of biological control in apple in central Washington and pear in northern Oregon was estimated by comparing pest management programs following practices thought to reduce negative impacts on natural enemies to programs following traditional practices. Pest management costs in three apple orchards that had transitioned to the use of codling moth mating disruption (CMMD) plus reduced-risk or organophosphate-alternative pesticides were compared with four orchards that had not adopted these practices. Pest management costs in five pear orchards using CMMD were compared to four orchards not using CMMD. In both cropping systems the impact of pest management programs on biological control was determined by the need to use pesticides to control secondary pests, aphids and spider mites in apple and spider mites and pear psylla in pear. The disruptive nature of pesticides was categorized into four levels from none (0) to high (4) based on data presented by Mills et al. (2016, this issue) and Beers et al. (2016, this issue), as well as other published information. Some reducedrisk and OP-alternative pesticides proved detrimental to natural enemies and disruptive of biological control in apple and pear. In apple, the use of pesticides with low risk to natural enemies reduced the need to apply controls for secondary pests. In pear, the use of CMMD reduced the need to control secondary pests, spider mites and pear psylla, in summer. The use of pesticides with a high risk to natural enemies increased the cost of secondary pest control by about $50 \%$ in apple and pear. A stepwise increase in natural enemy risk values increased total pest management costs by $\$ 46 /$ ha in natural enemy unfavorable apple orchards and by $\$ 44 /$ ha in pear orchards not using codling moth mating disruption.
\end{abstract}


Keywords: economic value, biological control, risk value, integrated pest

management, tree fruit 


\section{Introduction}

Managed systems like agriculture have long recognized the importance of a balanced approach to addressing pest issues. Integrated Pest Management (IPM) was born out of a crisis arising from the overuse of pesticides (Stern et al., 1959). IPM seeks to integrate biological, chemical, cultural and mechanical controls as core tactics to achieve a sustainable production system (Pedigo and Rice 2008). Biological control is typically considered a free service that, if managed, can contribute value and sustainability to IPM programs (DeBach, 1964; Kogan, 1998). While economics has always played a core role in the concept of IPM, according to Onstad and Knolhoff (2009) economic evaluations of IPM are rare, with less than $1 \%$ of articles published in four journals since 1972 including economic analyses. However, in a more recent review article, Naranjo et al. (2015) documented five examples of economic value specific to conservation biological control.

Recent studies have sought to assign value of habitat diversity as an ecosystem service that enhances conservation biological control (Fiedler et al., 2008; Griffiths et al., 2008; Landis et al., 2000). Losey and Vaughn (2006) estimated an economic value of natural control of insect pests to be $\$ 4.5$ billion annually for all U.S. crops. Cullen et al. (2008) provide a general discussion of the economics of conservation biological control but reported only one conservation biological control study that included an economic assessment. Headley and Hoy (1987) estimated that the value of conserving a genetically selected population of a predatory mite in almonds would save growers $\$ 24-44 / \mathrm{ha}$. Trumble and Morse (1993) reported that a combination of abamectin and augmentative 
releases of a predatory mite in strawberries provided net returns of $\$ 2,756-7,882 /$ ha compared to no controls.

In high-value perennial crops like apple, walnut, citrus and pear, the impact and potential of biological control is well documented (AliNiazee and Hagen, 1995; Gontijo et al., 2012; Headley and Hoy, 1987; Hoyt, 1969; Hoyt and Caltagirone, 1971; van den Bosch et al., 1979). In the late 1960s, Hoyt (1969) developed integrated mite control (IMC) where the western predatory mite, Galendromus occidentalis (Nesbitt), provided biological control of spider mites in an environment where insecticides were used to manage key pests like codling moth, Cydia pomonella (L.).

Integrating biological control in pear pest management programs has been more of a challenge than in apple. Pear production faces not only the challenge of controlling codling moth, but must also deal with pear psylla, Cacopsylla pyricola Foerster, which is considered to be a pest induced by the use of insecticides (Burts, 1983; Madsen et al., 1963; Westigard et al., 1986). Numerous studies have characterized a complex of natural enemies that attack pear psylla (Gut and Jochums, 1982; Madsen, 1961; Madsen et al., 1963; Nickel et al., 1965; Westigard et al., 1968; Westigard and Zwick, 1972; Zwick and Fields, 1977) as well as intra- and extra-orchard factors that influence biological control (Fye, 1983;_Gut and Jochums, 1982; Horton et al., 2002a; Horton et al., 2002b; Madsen et al., 1963; Miliczky and Horton, 2005; Nickel et al., 1965).

As reduced-risk insecticides have entered the market they have been adopted into western tree fruit IPM programs (Jones et al., 2009). While reduced-risk insecticides have made the orchard environment safer for farm workers, their impacts on natural enemies are poorly understood. Jones et al., (2016a, this issue) provide an overview of a USDA- 
SCRI project "Enhancing Biological Control in Western Orchard Systems" (EBCWOS), that sought to improve the long-term sustainability of IPM programs in apple, pear, and walnut in the western U.S. The EBCWOS project included an effort to capture the economic value of conservation biological control in apple and pear orchards in the Pacific Northwest. In this paper we used case studies in apple and pear orchards that did or did not follow practices that enhanced conservation biological control. We present an economic analysis from seven apple orchards over three years in north-central Washington and nine pear orchards over four years in northern Oregon to capture the value of conservation biological control.

\section{Methods - Case studies in apple and pear}

Insecticide and miticide use information was collected from seven apple orchards in north-central Washington over three years, 2007-2009. We grouped these orchards into two categories; orchards 1-3 that were considered natural enemy (NE) favorable because they had transitioned, or were in the process of transitioning, to the use of codling moth mating disruption (CMMD) and reduced-risk or organophosphate (OP) alternative insecticides, and orchards 4-7 that were that were considered NE unfavorable because they typically did not use CMMD and though they might have adopted use of some OPalternatives, they continued to use OP insecticides. For pears in northern Oregon, we collected insecticide and miticide use information from nine orchards over four years, 2007-2010. We grouped these orchards based on the use of CMMD. Orchards 1-5 used CMMD plus other pesticides in their pest management programs while orchards 6-9 did not use CMMD, relying solely on pesticides. 
Specific information about pesticide use and timing in apple and pear orchards is provided in Appendix A (Supplementary Tables S1 and S2). Any pesticides applied to apple in summer for control of spider mites or aphids were classified as secondary pest control. Similarly, any pesticides applied to pear in summer for spider mites or pear psylla were classified as secondary pest control.

A NE risk category (low, moderate or high) and NE risk value (1,2 or 3) was assigned to each pesticide based on information developed by the EBCWOS project (Mills et al., 2016, this issue). Where we did not have information from the EBWOS project on the effects of a pesticide on natural enemies, we relied on information from other published literature as summarized in the Orchard Pesticide Effects on Natural Enemies Database (OPENED) (Chambers et al., 2014). Information in OPENED was derived from several sources; including data generated from USDA-IFAFS and USDARAMP Areawide Codling Moth Control Program II projects, and information from Koppert Biological Systems, International Organization for Biological Control (IOBC), the Washington State University Tree Fruit Crop Protection Guide and publications of the University of California Extension, Cornell University, Ohio State University and Pennsylvania State University. For our study we used an average NE risk value for each pesticide from OPENED and rounded the average value to the nearest integer value $(1,2$ or 3) and assigned a complimentary NE risk category of low, moderate or high. The NE risk value allowed us to use a cumulative risk total for each apple and pear pest management program. We chose to assign a zero-risk to pheromones and Bacillus thuringiensis $(\mathrm{Bt})$, as these pesticides were deemed to have no impact on natural enemies. 
To establish a unit price for each pesticide we obtained information from two major agricultural chemical distributors that supplied orchard producers in Washington and Oregon. Prices we used were based on the average retail listings of 2010 prices from the two companies. The prices we used may slightly overestimate what growers pay since they often obtain reduced prices associated with bids for pesticides or because they receive a reduced price as part of an orchard management service agreement. We determined the unit cost of each pesticide, e.g. dollars per dry weight or fluid volume, and calculated the pesticide cost for each application as the amount used per ha times the unit price of the pesticide. The machinery cost was estimated at $\$ 20.38 / \mathrm{h}$ and the fuel cost at $\$ 12.38 / \mathrm{h}$ (Schnitkey and Lattz, 2008). Machinery repairs, maintenance, depreciation, and interest rate were estimated at $\$ 8 / \mathrm{h}$ (West et al., 2012). Labor cost for applying a pesticide (tractor driver) was set at $\$ 15.95 / \mathrm{h}$, assumed to be $10 \%$ higher than the accepted labor rate of $\$ 14.50 / \mathrm{h}$ (Schnitkey and Lattz, 2008). Each grower provided the time required to apply a pesticide. The total per ha cost of a pesticide application included the pesticide cost, machinery cost and labor cost. If more than one pesticide was used in an application (tank mix), the application costs were split between each pesticide. In addition, if an adjuvant was used in conjunction with a pesticide, such as a low rate of horticultural oil, the cost of the adjuvant was included as part of the cost of the pesticide. The total cost of an apple or pear pest management program each year was determined by accumulating the cost of each pesticide (insecticide or miticide and adjuvant) plus the machinery and labor costs.

Typically economic valuation of pest management programs have used a replacement cost method (Kaval and Baskaran, 2013), where value is based on replacing 
the cost of pesticide applications with alternative ecosystem services like biological control. We used the replacement cost method to value conservation biological control in apple and pear orchards. We had no information on the presence or abundance of pests or natural enemies in apple or pear orchards used in our study, but assumed that decisions of apple and pear growers to not or to apply pesticides to control secondary pests was evidence of the success or lack of success of conservation biological control.

By classifying pesticides by timing, target pest, NE risk category and value (Appendix A, Supplementary Tables S1 and S2) we were able to determine the cost of a grower's annual pest management program associated with these factors. For apple and pear we used a t-test to compare the total cost of pest management programs, the cost of secondary pest control, the number of pesticide applications and the number of pesticides applied. In addition we compared the cost of high- moderate- and low-risk pesticides and the cost of pheromone treatments as well as the cost of control of selected target pests and compared the cumulative risk values of high- moderate- and low-risk and total cumulative risk values for both apple and pear (JMP, 2013). We used regression analysis to compare the cost of high-risk insecticides to total program and secondary pest control costs and to compare the cumulative NE risk values to total program and secondary pest control costs (JMP, 2013).

\section{Results}

\subsection{Apple case study}


An average of 4.8 pesticide applications per ha were made over the three years in all apple orchards. There was no statistical difference in the average number of applications (trips through the orchard) between NE favorable and unfavorable orchards (Table 1). Pesticides are often applied as tank mixes so we also report the average number of pesticides applied, which was $5.0 \pm 1.7$ in NE favorable orchards and significantly lower than the $8.1 \pm 3.4$ in the NE unfavorable orchards (Table 1).

The average pest management cost in NE favorable orchards was $\$ 411 \pm 85 / \mathrm{ha}$, which was significantly lower than $\$ 930 \pm 479$ /ha in NE unfavorable orchards (Table 1). In addition, pest management costs in NE favorable orchards were more stable over time than in orchards 4-7, with the average cost of secondary pest control in NE favorable orchards being $\$ 11 \pm 34 / \mathrm{ha}$, which was significantly lower than $\$ 189 \pm 166 / \mathrm{ha}$ in NE unfavorable orchards (Table 1). Ninety-five percent of all secondary pest control costs, were attributed to NE unfavorable orchards. The average cost of high-risk pesticides in NE favorable orchards was $\$ 44 \pm 103 /$ ha, which was significantly lower than $\$ 280 \pm$ 195/ha in NE unfavorable orchards (Table 2). The cost of low- and moderate-risk pesticides was not different between NE favorable and NE unfavorable orchards.

The $\$ 302 \pm 100 /$ ha cost of codling moth control in NE favorable orchards was slightly lower, though not statistically different, from the $\$ 407 \pm 237 /$ ha for NE unfavorable orchards. There were no significant differences between the two orchard groups in leafroller or aphid control costs, however, the cost of mite control in NE favorable orchards was significantly lower compared to NE unfavorable orchards, $\$ 31 \pm$ 21/ha versus $\$ 151 \pm 80 /$ ha (Table 3). 
There was no relationship between the cost of high-risk pesticides and the cost of secondary pest control for NE favorable orchards, however, for NE unfavorable orchards there was a significant linear relationship $\left(\mathrm{y}=0.46 \mathrm{x}+61, R^{2}=0.45, P<0.001\right.$; Fig. 1$)$. For every $\$ 1$ spent on high-risk pesticides there was an extra $\$ 0.46$ in secondary pest control cost for these orchards.

The average cumulative NE risk value for NE favorable orchards was 7.2, which was significantly lower than the 22.9 for NE unfavorable orchards (Table 4). In addition, the average cumulative NE risk value for high- and moderate-risk insecticides in NE favorable orchards was significantly lower than for NE unfavorable orchards (Table 4).

For NE favorable orchards (Fig. 2A,B) there were no relationships between cumulative NE risk values and either total pest control cost $\left(R^{2}=0.03, P<0.67\right.$, Fig. $\left.2 \mathrm{~B}\right)$ or secondary pest control cost $\left(R^{2}=0.09, P<0.43\right)$. In contrast, for NE unfavorable orchards (Fig. 2A) there was a positive linear relationship between the cumulative NE risk values and total pest control cost $\left(\mathrm{y}=53 \mathrm{x}+155, R^{2}=0.60, P<0.003\right)$ such that for every unit increase in cumulative risk value there was a cost increase of $\$ 53 / \mathrm{ha}$. There was also a positive linear relationship $\left(\mathrm{y}=23 \mathrm{x}-167, R^{2}=0.50, P<0.01\right)$ between cumulative NE risk values and the cost of secondary pest control, indicating that for every unit increase of cumulative NE risk value there was a $\$ 23 /$ ha increase in the cost of secondary pest control (Fig. 2B).

\subsection{Pear case study}


Pear pest management costs are inherently high, 2.3 times higher than in apple (Table 1). Secondary pest control comprised $16 \%$ of total pest management costs in both apple and pear (Table 1). Pear psylla control comprised $46 \%$ of the all pear pest management costs and the combination of pear psylla and codling moth control comprised $73 \%$ of all pear pest management costs (Tables 1 and 3). An average of $8.6 \pm$ 1.5 applications per ha were made over four years in all pear orchards, with no statistical difference in the average number of applications (trips through the orchard) between CMMD and NO_CMMD orchards (Table 1). It is more common in pear than apple to have pesticides applied as tank mixes. The average number of pesticides applied to all pear orchards was $18.9 \pm 2.9$, with no difference between CMMD and NO_CMMD orchards (Table 1).

The average pest management cost in pear orchards was $\$ 1,647 \pm 269 /$ ha with no statistical differences between CMMD and NO_CMMD orchards. The average cost of secondary pest control in CMMD orchards was $\$ 188 \pm 133 / \mathrm{ha}$, which was significantly lower than NO_CMMD orchards, $\$ 370 \pm 138 /$ ha (Table 1).

There was a positive linear relationship between the cost of high-risk insecticides and the cost of secondary pest control in all pear orchards $\left(\mathrm{y}=0.41 \mathrm{x}-93, R^{2}=0.36, P<\right.$ 0.001). For every $\$ 1$ spent on high-risk insecticides there was an additional cost of $\$ 0.41$ for secondary pest control (Fig. 3).

The average cost of high- and moderate-risk pesticides in CMMD orchards was not statistically different from NO_CMMD orchards. However, the average cost of lowrisk pesticides in CMMD orchards was significantly higher than in NO_CMMD orchards, $\$ 864 /$ ha versus $\$ 576 /$ ha (Table 2). 
Pear psylla control accounted for $42 \%$ and $51 \%$ of total pest management costs in CMMD and NO_CMMD orchards, respectively. CMMD orchards spent an average of \$209/ha more on codling moth control than NO_CMMD orchards, due primarily to the cost of pheromone at $\$ 290 / \mathrm{ha}$ (Table 3). There was no statistical difference in the cost of mite control between CMMD and NO_CMMD orchards; however, the cost of aphid control in CMMD orchards was significantly higher than in NO_CMMD orchards, \$187 $\pm 73 /$ ha compared to $\$ 131 \pm 62 /$ ha (Table 3)

The average cumulative NE risk value in all pear orchards over four years was $25.0 \pm 5.3$ and there was no difference between CMMD and NO_CMMD orchards. In addition, the average cumulative NE risk value for high-, moderate- and low-risk insecticides was similar in CMMD and NO_CMMD orchards (Table 4).

There was a positive linear relationship between cumulative NE risk values and total pear pest management cost for CMMD orchards $\left(\mathrm{y}=44 \mathrm{x}+676, R^{2}=0.59, P<\right.$ 0.001, Fig. 4A), such that for every unit increase in the cumulative risk value there was a $\$ 44 /$ ha increase in the total cost of pest management. Although there was a positive trend for NO_CMMD orchards, it was not statistically significant $\left(\mathrm{y}=15.6 \mathrm{x}+1,143, R^{2}=\right.$ $0.16, P<0.13$, Fig. 4 A). There was a positive linear relationship between cumulative NE risk values and the cost of secondary pest control (Fig. 4B) for all pear orchards ( $y=20 x$ - 225, $R^{2}=0.40, P<0.006$ ) such that for every unit increase in cumulative risk value there was a $\$ 20 /$ ha increase in secondary pest control costs. For CMMD $(y=15 x-166$, $\left.R^{2}=0.35, P<0.006\right)$ and NO_CMMD $\left(\mathrm{y}=20 \mathrm{x}-144, R^{2}=0.47, P<0.004\right)$ orchards for every unit increase in the cumulative risk value there was an additional cost of $\$ 15 / \mathrm{ha}$ and $\$ 20 /$ ha in secondary pest control costs, respectively. 


\section{Discussion}

\subsection{Valuation of biological control in apple and pear}

While there are many examples of how pesticide selectivity has been used to conserve biological control in apple (Asquith and Hull, 1979; Burts, 1983; Croft, 1990; Hoyt, 1969), pear (Gut and Jochums, 1982; Madsen, 1961; Madsen et al., 1963; Nickel et al., 1965; Westigard et al., 1968; Westigard and Zwick, 1972; Zwick and Fields, 1977) and other crops (Croft, 1990; Johnson and Tabashnik, 1999), these examples do not provide an economic valuation of biological control. Probably the best documented success of conservation biological control comes from IMC in apple. For over four decades Washington apple growers have used selective insecticides to conserve the western predatory mite. Surveys of apple growers and crop consultants indicate that they valued biological control and understood which pesticides had negative impacts on natural enemies (Gadino et al., 2016, this isuue).

The stability of IMC can be documented by using information from the United States Department of Agriculture National Agricultural Statistics Service (USDA-NASS) pesticide use surveys in apples. Converting USDA-NASS data to ha-applications (haapplication $=$ the average number of applications times proportion of hectares treated) showed that an average of $0.28 \pm 0.17$ ha-applications of miticides were applied to Washington apples over the last twenty years (1991-2011). Using the same USDA-NASS data, an average of $0.88 \pm 0.46$ ha-applications of aphicides were used, and an average of $1.16 \pm 0.56$ ha-applications for aphicides and miticides combined. In our case study, NE 
favorable orchards had $0.17 \pm 0.35$ ha-applications and NE unfavorable orchards had 1.1 \pm 1.3 ha-applications of aphicides and miticides combined.

Assigning economic value to conservation biological control requires some assumptions. There is clearly an economic cost of using pesticides with a high risk to natural enemies. According to Hoyt (Hoyt, 1991; Hoyt and Caltagirone, 1971), the number of miticide applications per ha pre-IMC was between two and four per year. Assuming apple growers save two miticide applications per year by conserving predatory mites at an average current cost of $\$ 131 /$ ha (miticide plus application cost) from our study of (orchards 4-7), the savings would be $\$ 16.5$ million based on 63,000 ha. If this annual value of IMC were applied over the last four plus decades, the total cost savings would be over $\$ 450$ million. Putting an economic value of a conservation biological control program like IMC encourages pest management specialists to develop similar programs and helps growers to recognize the economic benefit of adopting practices that promotes conservation biological control.

Over the last ten years regulatory actions have eliminated or restricted the use of OP insecticides in apple production causing apple growers to transition to the use of OPalternatives. Many of the OP-alternative insecticides, e.g. acetamiprid, thiacloprid, and spineotram, have been shown to be of high risk to natural enemies (Appendix A, Tables S1 and S2). Apple orchards that used practices that promoted conservation biological control had a savings of $\$ 178 /$ ha in secondary pest control cost (Table 1). Our data also showed an economic impact on total pest management costs, where orchards that used practices promoting conservation biological control had a savings of $\$ 519 /$ ha (Table 1). Based on USDA-NASS pesticide use survey data about twenty-five percent of 
Washington apple production, $\approx 16,000$ ha, could benefit from enhanced conservation biological control and using a savings of $\$ 519 /$ ha from our results, the annual savings for the industry would be over $\$ 8$ million.

Pear differs from apple in its susceptibility to several pests, which makes conservation biological control more challenging. Pear is much more sensitive than apple to spider mites and rust mites. At relatively low spider mites densities, pear trees can experience defoliation, which can negatively impact fruit quality (Madsen and Barns, 1959; Westigard et al., 1966). Whereas the apple rust mite, Aculus schlechtendali (Nalepa), does not impact fruit quality, the pear rust mite, Epitrimerus pyri (Nalepa), causes a russet of pear fruit (Westigard, 1969). Therefore, instead of being an alternative food source for predatory mites and a stabilizing influence on biological control, the pear rust mite often requires pesticide applications to suppress its population.

Pear psylla has the potential to cause significant economic damage to pear. Historically, pear growers relied on insecticides to control pear psylla and codling moth and there is good evidence that these products, especially those used for codling moth, elevated pear psylla to key pest status by suppressing its natural enemies (Westigard, 1973; Westigard et al., 1968). Thus the availability of CMMD represented an opportunity to develop pear pest management programs that could enhance biological control of pear psylla (Westigard and Moffit, 1984).

We applied the same approach of economic valuation of conservation biological control in pear as in apple. Based on the assumption that codling moth control was responsible for the induction of pear psylla problems, growers in northern Oregon began utilizing CMMD. There was no difference in total pest management cost between the 
CMMD and NO_CMMD orchards (Table 1). However, there was a significant difference in secondary pest control of $\$ 182 /$ ha between CMMD and NO_CMMD orchards (Table 1). While the difference in cost of secondary pest control is encouraging and suggests a value for conservation biological control, the difference was not sufficient to offset the cost of pheromones plus a greater investment in low-risk pesticides (Table 2).

One issue that was clear from our study was that pear growers invest a large amount of resources in the early part of the growing season targeting pear psylla and to lessor extent mites. For example, early season pear psylla control averaged $\$ 569 \pm$ 118/ha, representing $34.5 \%$ of total pear pest management costs. While $58 \%$ of the pesticides applied for early season pear psylla control were of low risk, $20 \%$ were high risk to natural enemies (Appendix A, Table S2). Of those high-risk pesticides, endosulfan, thimethoxam and lambda-cyhalothrin were applied most often. In addition, both programs used high-risk pesticides to manage codling moth in the summer, even those using CMMD (Appendix A, Table S2). For pear growers to capture the economic value of conservation biological control through the adoption of CMMD they will need to reduce use of high-risk pesticides. It should be possible to increase the use of low-risk pesticides for codling moth control and to use more low-risk pesticides in the early part of the growing season, which should allow for an earlier establishment of natural enemies to enhance biological control of pear psylla.

A confounding factor in our study was that both CMMD and NO_CMMD orchards changed practices over the four years of our study. For example, the cost of high-risk pesticides in CMMD orchards declined from $\$ 694 /$ ha in year one to $\$ 224 /$ ha in 
year four. A similar pattern was observed for NO_CMMD orchards, where the costs of high-risk pesticides declined from $\$ 599 /$ ha in year one to $\$ 225 /$ ha in year four.

Concurrent changes in practices associated with studies comparing different pest management programs is common as growers begin to see advantages of new practices being adopted by their peers (Goldberger et al., 2011). Evidence of this potential comes from pear growers in the Hood River Valley of Oregon who, since this case study, have continued to adopt the use of CMMD and are reporting fewer problems with pear psylla and spider mites (Castagnoli, 2015). In order to take maximum advantage of biological control of pear psylla, the role of natural enemies in pear orchards in spring and early summer needs further examination.

\subsection{Natural enemy risk indices}

Various indices have been proposed as a means of evaluating the relative risk or impacts of pest management programs. Kovach et al. (1992) developed an Environmental Impact Quotient (EIQ) by assigning a numerical value to pesticides based on inherent toxicity to mammals, wildlife and beneficial insects, persistence, and run off potential. The EIQ was designed to compare different pest management programs for their relative impacts on the environment, but not as a measure of pest management program quality or of the impact of a pest management program on biological control. Walker et al. (1997) developed a pesticide rating system to track changes in agrichemical use in New Zealand. Their system was based on assigning values (1-10) to pesticides for consumer, worker and environmental risk. Penrose et al. (1994) proposed a risk rating system that balanced the beneficial aspects of pesticides with potential undesirable 
effects. The intended use of their risk rating system was to provide a quantitative measure that could be used to document reductions in high-risk pesticides or to accredit pest management programs with reduced pesticide residues. Thomson and Hoffmann (2006) used International Organization for Biological Control (IOBC) risk rating values and found that certain natural enemy groups such as spiders, lacewings, carabids and parasitoids were most affected by pesticide use in commercial vineyards, while others such as predatory bugs and syrphids, were less affected. These authors (Thomson and Hoffmann, 2007) also proposed a risk rating system that included a combination of toxicity indices, persistence, deleterious impact to natural enemies and the potential for natural enemy reestablishment.

Based on experience in the EBCWOS project (Beers et al., 2016, this issue; Shearer et al., 2016, this issue), we know that applying insecticides with high-risk to natural enemies does not automatically result in the disruption of biological control. However, the cumulative effect of pesticide applications over a growing season could negatively impact natural enemies and result in outbreaks of secondary pests. By assigning a numerical natural enemy risk value to each pesticide we were able to estimate cumulative risk of pest management programs over the growing season. In apple orchards as cumulative NE risk values increased so did the total cost of pest management programs as well as the cost of secondary pest control (Fig. 2B) and a similar pattern was observed in pear (Fig. 4B). By assigning risk values to pesticides allows for the accumulating these values over a growing season providing a mechanism to rate the risk or potential impact of different pest management programs relative to conservation biological control. With more data from different kinds of apple and pear orchards it 
might be possible to identify levels of cumulative risk values that would signal that a pest management program was approaching a dangerous level for disrupting biological control allowing growers to opt for use of low-risk pesticides to reduce the risk of disruption.

The impact of a pesticide can be made more selective by adjusting application rate, thus reducing the potential negative impact on natural enemies, or adjusting the time of application to minimize exposure of natural enemies to the pesticide (Agnello et al., 2003; Hoyt, 1969; Hull et al., 1985; Johnson and Tabashnik, 1999). For example, Brunner et al. (2001) showed that while abamectin had a high acute toxicity to Colpoclypeus florus (Walker), a leafroller parasitoid, and Trichogramma platneri Nagarkatti, an egg parasitoid of many Lepidoptera, residues on foliage showed no toxicity to $C$. florus after one day and to T. platneri after seven days. As more becomes known about the effects of pesticide rates and persistence on natural enemies, risk values could be adjusted to reflect a more realistic impact. As models for natural enemies are developed and implemented into decision support systems like the WSU Tree Fruit Decision Aid System (Jones et al., 2010), growers would know when natural enemies are likely to be present in their orchards giving them a tool to reduce the impact of an inherently high-risk pesticide by adjusting the rate used or the time during the season it is applied.

Gallardo and Wang (2013) found that Washington apple growers were willing to pay $\$ 66 /$ ha to decrease an insecticide's probability of being toxic to natural enemies, $\$ 153 /$ ha to decrease toxicity for wildlife, and $\$ 107 /$ ha to decrease toxicity for aquatic organisms. Likewise Oregon pear growers were willing to pay $\$ 82 /$ ha to decrease an 
insecticide's probability of toxicity for natural enemies, $\$ 62 /$ ha to decrease toxicity for wildlife and $\$ 49 /$ ha to decrease toxicity for aquatic organisms. The results from our case studies document the economic incentive behind the willingness of Washington apple and Oregon pear growers to invest in practices that enhance conservation biological control. We have demonstrated, using real commercial orchards pest control programs, that there is a tangible economic benefit from adopting such practices. Other less-tangible benefits from using conservation biological control that were not captured in this study, such as the value of consumer's willingness to pay for fruit from growers that follow practices that are friendly to the environment, merit further analyses. 


\section{Acknowledgements}

Our appreciation is to the grower cooperators for their willingness to share pesticide use data that provided the basis for our economic analysis of conservation biological control. The research personnel and technical support of the laboratories from Washington State University, Oregon State University, University of California Berkeley and USDA-ARS Yakima are gratefully acknowledged. Funding and support of this project was provided through USDA-SCRI Grant No. 2008-04854 and matching funds by Washington Tree Fruit Research Commission, Washington State Commission on Pesticide Registration, California Walnut Board, and Hood River (Oregon) Pear Growers. 


\section{References}

Agnello, A.M., Reissig, W.H., Kovach, J., Nyrop, J.P., 2003. Integrated apple pest management in New York State using predatory mites and selective pesticide. Agric. Ecosys. \& Environ. 94, 183-195.

Aliniazee, M.T., Hagen, K.S., 1995. Walnut Aphid - Part I, in: Nechols, J.R. (Ed.), Biological Control in the Western United States: Accomplishments and Benefits of Regional Research Project W-84, 1964-1989. UCANR Publication 3361, Oakland, CA. pp. $140-141$.

Asquith, D., Hull, L.A., 1979. Integrated pest management systems in Pennsylvania apple orchards, in: Bothel, D.J., Eikenbary, R.D. (Eds.), Pest Management Programs for Deciduous Tree Fruits and Nuts. Springer, New York, NY, pp. 203-222.

Beers, E.H., Mills, N.J., Shearer, P.W., Horton, D.R., Milickzy, E., Amarasekare, K.G., 2016. Nontarget effects of orchard pesticides on natural enemies: lessons from the field and laboratory. Biol. Control, this issue.

Brunner, J.F., Dunely, J.D., Doerr, M.D., Beers, E.H., 2001. Effect of pesticides on Colpoclypeus florus (Hymenoptera: Eulophidae) and Trichogramma platneri (Hymenoptera: Trichogrammatidae), parasitoids of leafroller in Washington. J. Econ. Entomol. 94, 1075-1084.

Burts, E.C., 1983. Effectiveness of a soft-pesticide program on pear pests. J. Econ. Entomol. 76, 936-941.

Castagnoli, S., Personal communication. March 2015. 
Croft, B.A., 1990. Arthropod Biological Control Agents and Pesticides. John Wiley and Sons Inc, New York, NY.

Chambers, U., Jackson, C., Brunner, J.F., Jones, V.P., 2014. OPENED - Orchard Pesticide Effects on Natural Enemies Database. http://enhancedbiocontrol.org/opened [last accessed January 3, 2016].

Cullen, R., Warner, K.D., Jonsson, M., Wratten, S.D., 2008. Economics and adoption of conservation biological control. Biol. Control 45, 272-280.

DeBach, P., 1964. The scope of biological control, in: DeBach, P. (Ed.), Biological Control of Insect Pests and Weeds. Reinhold, New York, NY, pp. 3-20.

Fiedler, A.K., Landis, D.A., Wratten, S.D., 2008. Maximizing ecosystem services from conservation biological control: The role of habitat management. Biol. Control 45, 254-271.

Fye, R.E., 1983. Cover crop manipulation for building pear psylla (Homoptera: Psyllidae) predator populations in pear orchards. J. Econ. Entomol. 76, 306-310.

Gadino, A.N., Brunner, J.F., Chambers, U., Jones, W.E., Castagnoli, S., Jones, V. P., 2016. A perspective on the extension of research-based information to orchard management decision-makers: lessons learned and potential future directions. Biol. Control, this issue.

Gallardo, R.K., Wang, Q., 2013. Willingness to pay for insecticides’ environmental features and social desirability bias: The case of apple and pear growers. J. Agr. Res. Econ. 38, 1-16. 
Goldberger, J.R., Lehrer, N. and Brunner, J.F., 2011. Azinphos-methyl (AZM) phase-out: Actions and attitudes of apple growers in Washington State. Ren. Agr. Food Sys. 26, 276-286.

Gontijo, L., Cockfield, S.D., Beers, E.H., 2012. Natural enemies of woolly apple aphid (Hemiptera: Aphididae) in Washington state. Environ. Entomol. 41, 1364-1371.

Griffiths, G.J.K., Holland, J.M., Bailey, A., Thomas, M.B., 2008. Efficacy and economics of shelter habitats for conservation biological control. Biol. Control 45, 200-209.

Gut, L., Jochums, C., 1982. Variations in pear psylla (Psylla pyricola Foerster) densities in southern Oregon orchards and its implications. Acta Hortic. 124, 101-111.

Headley, J.C., Hoy, M.A., 1987. Benefit/cost analysis of an integrated mite management program for almonds. J. Econ. Entomol. 80, 555-559.

Horton, D.R., Broers, D.A., Lewis, R.R., Granatstein, D., Zack, R.S., Unruh, T.R., Moldenke, A.R., Brown, J.J., 2002a. Effects of mowing frequency on densities of natural enemies in three Pacific Northwest pear orchards. Entomol. Exp. Appl. 106, $135-145$.

Horton, D.R., Broers, D.A., Hinojosa, T., Lewis, T.M., Miliczky, E.R., Lewis, R.R., 2002b. Diversity of predatory arthropods overwintering in cardboard bands placed in pear and apple orchards of central Washington state. Ann. Entomol. Soc. Am. 95, $469-480$.

Hoyt, S.C., 1969. Integrated chemical control of insects and biological control of mites on apple in Washington. J. Econ. Entomol. 62, 74-86. 
Hoyt, S.C., 1991. Biology, ecology, and control of mites in Washington orchards, in: Williams, K. (Ed.), New Directions in Tree Fruit Management. Good Fruit Grower, Yakima, WA, pp. 147-156.

Hoyt, S.C., Caltagirone, L.E., 1971. The developing programs of integrated control of pests in apples in Washington and peaches in California, in: Huffaker, C.B. (Ed.), Biological Control. Plenum, New York, NY, pp. 395-421.

Hull, L.A., Beers, E.H., Meagher, R.L., 1985. Integration of biological and chemical control tactics for apple pests through selective timing and choice of synthetic pyrethroids insecticides. J. Econ. Entomol. 78, 714-721.

$\mathrm{JMP}^{\circledR}$, Version 11, 2013. SAS Institute Inc., Cary, NC.

Johnson, M.W., Tabashnik, B.E., 1999. Enhanced biological control through pesticide selectivity, in: Fisher, T.W., Bellows, T.S., Caltagirone, L.E., Dahlsten, D.L., Huffaker, C.B., Gordh, G. (Eds.), Handbook of biological control: principles and applications of biological control. Academic Press, San Diego, CA, pp. 297-31.

Jones V.P., Brunner, J.F., Grove, G.G., Petit, B., Tangren, G.V., Jones, W.E., 2010. A web-based decision support system to enhance IPM programs in Washington tree fruit. Pest Manage. Sci. 66, 587-595.

Jones V.P., Unruh T.R., Horton D.R., Mills N.J., Brunner J.F., Beers E.H., Shearer P.W., 2009. Tree Fruit IPM Programs in the Western United States: The challenge of enhancing biological control through intensive management. Pest Manage. Sci. 65, $1305-1310$.

Jones, V.P., Mills, N.J., Brunner, J.F., Horton, D.R., Beers, E.H., Unruh, T.R., Shearer, P. W., Goldberger, J.R., Gastagnoli, S., Lehrer, N., Miliczky, E., Steffan, S.A., 
Amarasekare, K.G., Chambers, U., Gadino, A.N., Gallardo, R.K., 2016a. From planning to execution to the future: An overview of a concerted effort to enhance biological control in western apple, pear, and walnut orchards in the western U.S. Biol. Control, this issue.

Jones, W.E., Chambers, U., Gadino, A.N., Brunner, J.F., 2016b. Web-based outreach for orchard management decision-makers. Biol. Control, this issue.

Kaval, P., Baskaran, R., 2013. Key ideas and concepts from economics for understanding the roles and value of ecosystem services, in: Wratten, S.D., Sandhu, H., Cullen, R., Costanza, R. (Eds.), Ecosystem Services in Agricultural and Urban Landscapes. John Wiley \& Sons, New York, NY, pp. 28-41.

Kogan, M., 1998. Integrated pest management: historical perspectives and contemporary developments. Annu. Rev. Entomol. 43, 243-270.

Kovach, J., Petzoldt, C., Degni, J., Tette, J., 1992. A method to measure the environment impact of pesticides. New York's Food Life Sci. Bull. 139, New York State Agriculture Exp. Sta. Geneva, New York, 8pp.

Landis, D.A., Wratten, S.D., Gurr, G.M., 2000. Habitat management to conserve natural enemies of arthropod pests in agriculture. Annu. Rev. Entomol. 45, 175-201.

Losey, J.E., Vaughan, M., 2006. The economic value of ecological services provided by insects. BioScience 56, 311-323.

Madsen, H.F., Barnes, M.M., 1959. Pests of pear in California. Calif Agr. Exp. Sta. Extension Service Circular, 478, 40pp.

Madsen, H.F, 1961. Notes on Anthocoris melanocerus Reuter (Hemiptera:Anthocirdae) as a predator of the pear psylla in British Columbia. Can. Entomol. 93, 660-662. 
Madsen, H.F., Westigard, P.H., Sisson, R.L., 1963. Observations on the natural control of the pear psylla, Psylla pyricola Förster, in California. Can. Entomol. 95, 837-844.

Miliczky, E.R., Horton, D.R., 2005. Densities of beneficial arthropods within pear and apple orchards affected by distance from adjacent native habitat and association of natural enemies with extra-orchard host plants. Biol. Control 33, 249-259.

Mills, N.J., Beers, E.H., Shearer, P.W., Unruh, T.R., Amarasekare, K.G., 2016. Comparative analysis of pesticide effects on natural enemies in western orchards: a synthesis of laboratory bioassay data. Biol. Control, this issue

Naranjo, S.E., Ellsworth, P.C., Frisvold, G.B., 2015. Economic value of biological control in integrated pest management plant systems. Annu. Rev. Entomol. 60, 621645.

Nickel J.L., Shimizu, J.T., Wong, T.Y., 1965. Studies on natural control of pear psylla in California. J. Econ. Entomol. 58, 970-976.

Onstad, D.W., Knolhoff, L.M., 2009. Finding the economics in economic entomology. J. Econ. Entomol. 102, 1-7.

Pedigo, L.P., Rice, M., 2008. Entomology and Pest Management, sixth ed. Prentice Hall, Upper Saddle River, NJ.

Penrose, L.J., Thwaite, W.G., Bower C.C., 1994. Rating index as a basis for decision making on pesticide use reduction and for accreditation of fruit produced under integrated pest management. Crop Prot. 13, 146-152.

Schnitkey, G., Lattz, D., 2008. Farm Business Management Machinery Cost Estimates: Tractors. Department of Agricultural and Consumer Economics, University of Illinois, Urbana, IL. 
Shearer, P.W., Amarasekare, K.G., Castagnoli, S., Beers, E.H., Jones, V.P., Mills, N.J., 2016. Large-plot field studies to assess impacts of newer insecticides on non-target arthropods in Western U. S. orchards. Biol. Control, this issue.

Stern V.M., Smith, R.F., van den Bosch R., Hagen K.S., 1959. The integrated control concept. Hilgardia 29, 81-101.

Thomson, L.J., Hoffman, A.A., 2006. Field evaluation of laboratory-derived IOBC toxicity ratings for natural enemies in commercial vineyards. Biol. Control 39, 507515.

Thomson, L.J., Hoffman, A.A., 2007. Ecologically sustainable chemical recommendations for agricultural pest control? J. Econ. Entomol. 100, 1741-1750.

Trumble, J.T., Morse, J.P., 1993. Economics of integrating the predaceous mite Phytoseiulus persimilis (Acari: Phytoseiidae) with pesticides in strawberries. J. Econ. Entomol. 86, 879-885.

USDA-NASS, 2012. Quick Stats 2.0 (quickstats.nass.usda.gov) [Accessed September and 2012].

van den Bosch, R., Hom, R., Matteson, P., Frazer, B., Messenger, P., Davis, C., 1979. Biological control of the walnut aphid in California: Impact of the parasite, Trioxys pallidus. Hilgardia 47,1-13.

Walker, J.T.S., Hodson, A.J., Barchelor, T.A., Manktelow, D.W., Tomkins, A.R., 1997. A pesticide rating system for monitoring agrichemical inputs in New Zealand horticulture. Proc. 50 ${ }^{\text {th }}$ N.Z. Plant Prot. Conf. 50, 529-534. 
West, T.,Sullivan, R., Seavert, C., Castagnoli, S., 2012. Enterprise Budgets Apples, Medium Density, North Central Region. Extension Factsheet AEB0024, Oregon State University, Corvallis, OR.

Westigard, P.H., 1969. Timing and evaluation of pesticides for control of the pear rust mite. J. Econ. Entomol. 62, 1158-1161.

Westigard, P.H., 1973. Pest status of insects and mites on pear in southern Oregon. J. Econ. Entomol. 166, 227-232.

Westigard, P.H., Gentner, L.G., Berry, D.W., 1968. Present status of biological control of the pear psylla in southern Oregon. J. Econ. Entomol. 61, 740-743.

Westigard, P.H., Gut, L.J., Liss, W.J., 1986. Selective control program for the pear pest complex in southern Oregon. J. Econ. Entomol. 79, 250-257.

Westigard, P.H., Lombard, P.B., Grim, J.H., 1966. Preliminary investigations of the effect of feeding of various levels of the two-spotted mite on its Anjou pear host Amer. Soc. Hort. Sci. 89, 117-122.

Westigard, P.H., Moffit, H.R., 1984. Natural control of the pear psylla (Homoptera: Psyllidae): impact of mating disruption with the sex pheromone for control of the codling moth (Lepidoptera: Tortricidae). J. Econ. Entomol. 77, 1520-1523.

Westigard, P.H., Zwick, R.W., 1972. The pear psylla in Oregon. Oregon Agric. Exp. Stn. Tech. Bull. 122, 22pp.

Zwick, R.W., Fields, G.J., 1977. Integrated control of pear psylla in Oregon's Hood River Valley. Oregon Agric. Exp. Stn. Circ. Inf. 660, 8pp. 


\section{Table and Figure Captions}

Table 1. Average cost of total pest management program and secondary pest control, and the average number of pesticide applications made and number of pesticides applied to apple and pear orchards.

Table 2. Average cost of pesticides with high-risk, moderate-risk and low-risk to natural enemies and the average cost of pheromones applied to apple and pear orchards.

Table 3. Average cost of pesticides for control of codling moth, leafrollers, mites and aphids in apple orchards and control of codling moth, pear psylla, mites and scale in pear orchards.

Table 4. Average cumulative risk values for high-risk, moderate-risk, low-risk and total pesticides applied to apple and pear orchards.

Fig. 1. Relationship between the cost of insecticides with a high-risk to natural enemies and the cost of secondary pest control (summer aphids and spider mites) in apple, 20072009. Filled circles represent NE favorable orchards while open circles represent NE unfavorable orchards.

Fig. 2. Relationship between cumulative NE risk values and (A) the total cost of pest management programs and (B) the cost of secondary pest control in apple orchards. Filled circles represent NE favorable orchards while open circles represent NE unfavorable orchards.

Fig. 3. Relationship between the cost of high-risk insecticides and the cost of secondary pest control (summer pear psylla and spider mites) in pear, 2007-2010. Filled circles represent orchards using CMMD while open circles represent NO_CMMD orchards. 
Fig. 4. Relationship between cumulative NE risk values and (A) the total cost of pest control programs and (B) the cost of secondary pest control in pear orchards. Filled circles represent CMMD orchards while open circles represent NO_CMMD orchards. 
Table 1. Average cost of total pest management program and secondary pest control, and the average number of pesticide applications made and number of pesticides applied to apple and pear orchards.

\begin{tabular}{|c|c|c|c|c|c|}
\hline Crop/Program & Orchard & $\begin{array}{c}\text { Mean program cost } \\
\text { per ha } \pm \mathrm{SD}^{1}\end{array}$ & $\begin{array}{r}\text { Mean secondary pest } \\
\text { cost per ha } \pm \mathrm{SD}^{2}\end{array}$ & $\begin{array}{l}\text { Mean no. } \\
\text { applications } \pm \mathrm{SD}\end{array}$ & $\begin{array}{c}\text { Mean no. } \\
\text { pesticides } \pm \mathrm{SD}^{3}\end{array}$ \\
\hline Apple & Orchards 1-7 & $708 \pm 446$ & $113 \pm 154$ & $4.8 \pm 1.4$ & $6.8 \pm 3.1$ \\
\hline NE favorable & Orchards 1-3 & $411 \pm 83 a$ & $11 \pm 9 a$ & $4.1 \pm 0.9 \mathrm{a}$ & $5.0 \pm 1.7 \mathrm{a}$ \\
\hline NE unfavorable & Orchards 4-7 & $930 \pm 474 b$ & $189 \pm 166 b$ & $5.3 \pm 1.5 \mathrm{a}$ & $8.1 \pm 3.4 b$ \\
\hline Pear & Orchards 1-9 & $1647 \pm 269$ & $269 \pm 162$ & $8.6 \pm 1.5$ & $18.9 \pm 2.9$ \\
\hline CMMD & Orchards 1-5 & $1722 \pm 304 \mathrm{a}$ & $188 \pm 133 \mathrm{a}$ & $8.7 \pm 1.7 \mathrm{a}$ & $18.4 \pm 3.2$ \\
\hline NO_CMMD & Orchards 6-9 & $1553 \pm 479 a$ & $370 \pm 138 b$ & $8.6 \pm 1.6 \mathrm{a}$ & $19.7 \pm 2.4$ \\
\hline
\end{tabular}

${ }^{1}$ Average cost of total pest controll followed by different letters are statistically different; Apple $-t=3.2, d f=19, P<0.005$.

2 Average cost of secondary pest control followed by different letters are statistically different; Apple $-t=2.8, d f=19, P<0.01$; Pear $-t=3.5, d f=35, P=0.01$.

${ }^{3}$ Average number of pesticides applied followed by different letters are statistically different; Apple $-t=5.3, d f=19, P<0.001$. 
Table 2. Average cost of pesticides with high-risk, moderate-risk and low-risk to natural enemies and the average cost of pheromones applied to apple and pear orchards.

\begin{tabular}{|c|c|c|c|c|c|}
\hline Crop/Program & Orchard & $\begin{array}{l}\text { Mean high risk } \\
\text { cost per ha } \pm \mathrm{SD}^{1}\end{array}$ & $\begin{array}{l}\text { Mean moderate risk } \\
\text { cost per ha } \pm \text { SD }\end{array}$ & $\begin{array}{c}\text { Mean low risk } \\
\text { cost per ha } \pm \mathrm{SD}^{2}\end{array}$ & $\begin{array}{l}\text { Mean pheromone } \\
\text { cost per ha } \pm \mathrm{SD}^{3}\end{array}$ \\
\hline Apple & Orchards 1-7 & $178 \pm 199$ & $33 \pm 65$ & $332 \pm 150$ & $109 \pm 106$ \\
\hline NE favorable & Orchards 1-3 & $44 \pm 103 a$ & $8 \pm 24 a$ & $336 \pm 145 a$ & $122 \pm 70 a$ \\
\hline NE unfavorable & Orchards 4-7 & $280 \pm 195 b$ & $52 \pm 80 a$ & $328 \pm 159 a$ & $100 \pm 129 b$ \\
\hline Pear & Orchards 1-7 & $428 \pm 236$ & $365 \pm 126$ & $736 \pm 227$ & $162 \pm 146$ \\
\hline CMMD & Orchards 1-5 & $395 \pm 245 a$ & $336 \pm 130 a$ & $864 \pm 188 b$ & $290 \pm 0 \mathrm{~b}$ \\
\hline NO_CMMD & Orchards 6-9 & $469 \pm 226 \mathrm{a}$ & $402 \pm 113 \mathrm{a}$ & $576 \pm 161 \mathrm{a}$ & $0 \pm \quad 0 \mathrm{a}$ \\
\hline
\end{tabular}

1 Average cost of high risk pesticides followed by different letters are statistically different; Apple $-t=5.1, d f=19, P<0.05$.

2 Average cost of low risk pesticides followed by different letters are statistically different; Apple $-t=3.8, d f=19, P<0.003$.

${ }^{3}$ Average cost of pheromones followed by different letters are statistically different; Apple $-t=3.8, d f=19, P<0.003$;

Pear $-t=4.0, d f=35, P<0.05$. 
Table 3. Average cost of pesticides for control of codling moth, leafrollers, mites and aphids in apple orchards and control of codling moth, pear psylla, mites and scale in pear orchards.

\begin{tabular}{|c|c|c|c|c|c|}
\hline Crop/Program & Orchard & $\begin{array}{l}\text { Mean codling moth } \\
\text { cost per ha } \pm \text { SD }\end{array}$ & $\begin{array}{l}\text { Mean leafroller cost } \\
\text { per ha } \pm \text { SD }\end{array}$ & $\begin{array}{c}\text { Mean mite cost } \\
\text { per ha } \pm \mathrm{SD}^{2}\end{array}$ & $\begin{array}{c}\text { Mean aphid cost } \\
\text { per ha } \pm \text { SD } \\
\end{array}$ \\
\hline Apple & Orchards 1-7 & $362 \pm 195$ & $106 \pm 79$ & $99 \pm 86$ & $46 \pm 95$ \\
\hline NE favorable & Orchards 1-3 & $302 \pm 100 \mathrm{a}$ & $48 \pm 31 a$ & $31 \pm 21 \mathrm{a}$ & $5 \pm 15 a$ \\
\hline NE unfavorable & Orchards 4-7 & $407 \pm 237 \mathrm{a}$ & $150 \pm 76 a a$ & $151 \pm 80 b$ & $77 \pm 118 \mathrm{a}$ \\
\hline Crop/Program & Orchard & $\begin{array}{l}\text { Ave. codling moth } \\
\text { cost per ha } \pm \mathrm{SD}^{1}\end{array}$ & $\begin{array}{l}\text { Ave. pear psylla } \\
\text { cost per ha } \pm \text { SD }\end{array}$ & $\begin{array}{l}\text { Ave. mite cost } \\
\text { per ha } \pm \text { SD }\end{array}$ & $\begin{array}{l}\text { Ave. scale cost } \\
\text { per ha } \pm \mathrm{SD}^{3}\end{array}$ \\
\hline Pear & Orchards 1-7 & $431 \pm 163$ & $751 \pm 155$ & $296 \pm 105$ & $162 \pm 73$ \\
\hline CMMD & Orchards $1-5$ & $524 \pm 133 b$ & $718 \pm 121 \mathrm{a}$ & $281 \pm 129 a$ & $187 \pm 73 b$ \\
\hline NO_CMMD & Orchards 6-9 & $315 \pm 115 a$ & $792 \pm 185 \mathrm{a}$ & $316 \pm 63 a$ & $131 \pm 62 \mathrm{a}$ \\
\hline
\end{tabular}

${ }^{1}$ Average cost of codling moth control followed by different letters are statistically different; Pear $-t=5.2, d f=34, P<0.001$.

2 Average cost of mite control followed by different letters are statistically different; Apple $-t=4.6, d f=19, P<0.002$.

${ }^{3}$ Average number of scale control applied followed by different letters are statistically different; Pear $-t=2,2, d f=34, P<0.04$. 
Table 4. Average cumulative risk values for high-risk, moderate-risk, low-risk and total pesticides applied to apple and pear orchards.

\begin{tabular}{|c|c|c|c|c|c|}
\hline Crop/Program & Orchard & $\begin{array}{l}\text { Mean cumulative } \\
\text { high risk } \\
\text { value } \pm \mathrm{SD}^{1}\end{array}$ & $\begin{array}{l}\text { Mean cumulative } \\
\text { moderate risk } \\
\text { value } \pm \mathrm{SD}^{2}\end{array}$ & $\begin{array}{c}\text { Mean cumulative } \\
\text { low risk } \\
\text { value } \pm \mathrm{SD}\end{array}$ & $\begin{array}{c}\text { Mean cumulative } \\
\text { total risk } \\
\text { value } \pm \mathrm{SD}^{3}\end{array}$ \\
\hline Apple & Orchards 1-7 & $6.1 \pm 6.1$ & $1.2 \pm 1.6$ & $2.7 \pm 1.0$ & $16.3 \pm 12.8$ \\
\hline NE favorable & Orchards 1-3 & $2.0 \pm 3.4 \mathrm{a}$ & $0.2 \pm 0.7 \mathrm{a}$ & $3.0 \pm 1.1$ & $7.2 \pm 6.3 \mathrm{a}$ \\
\hline NE unfavorable & Orchards 4-7 & $9.3 \pm 5.9 \mathrm{~b}$ & $2.0 \pm 1.7 \mathrm{~b}$ & $2.4 \pm 0.9$ & $22.9 \pm 12.5 b$ \\
\hline Pear & Orchards 1-7 & $10.2 \pm 5.4$ & $6.3 \pm 2.2$ & $8.8 \pm 2.5$ & $25.0 \pm 5.3$ \\
\hline CMMD & Orchards 1-5 & $9.6 \pm 5.4 \mathrm{a}$ & $5.6 \pm 1.1 \mathrm{a}$ & $9.2 \pm 2.6 \mathrm{a}$ & $24.0 \pm 5.4 \mathrm{a}$ \\
\hline NO_CMMD & Orchards 6-9 & $10.9 \pm 5.6 \mathrm{a}$ & $7.1 \pm 2.4 \mathrm{a}$ & $8.4 \pm 2.4 \mathrm{a}$ & $26.4 \pm 4.8 \mathrm{a}$ \\
\hline
\end{tabular}

1 Average NE high-risk values followed by different letters are statistically different; Apple $-t=3.3, d f=19, P<0.05$.

2 Average NE moderate-risk values followed by different letters are statistically different; Apple $-t=3.4, d f=19, P<0.05$.

${ }^{3}$ Average total NE risk values followed by different letters are statistically different; Apple $-t=4.2, d f=19, P<0.05$. 
Abstract Fig.

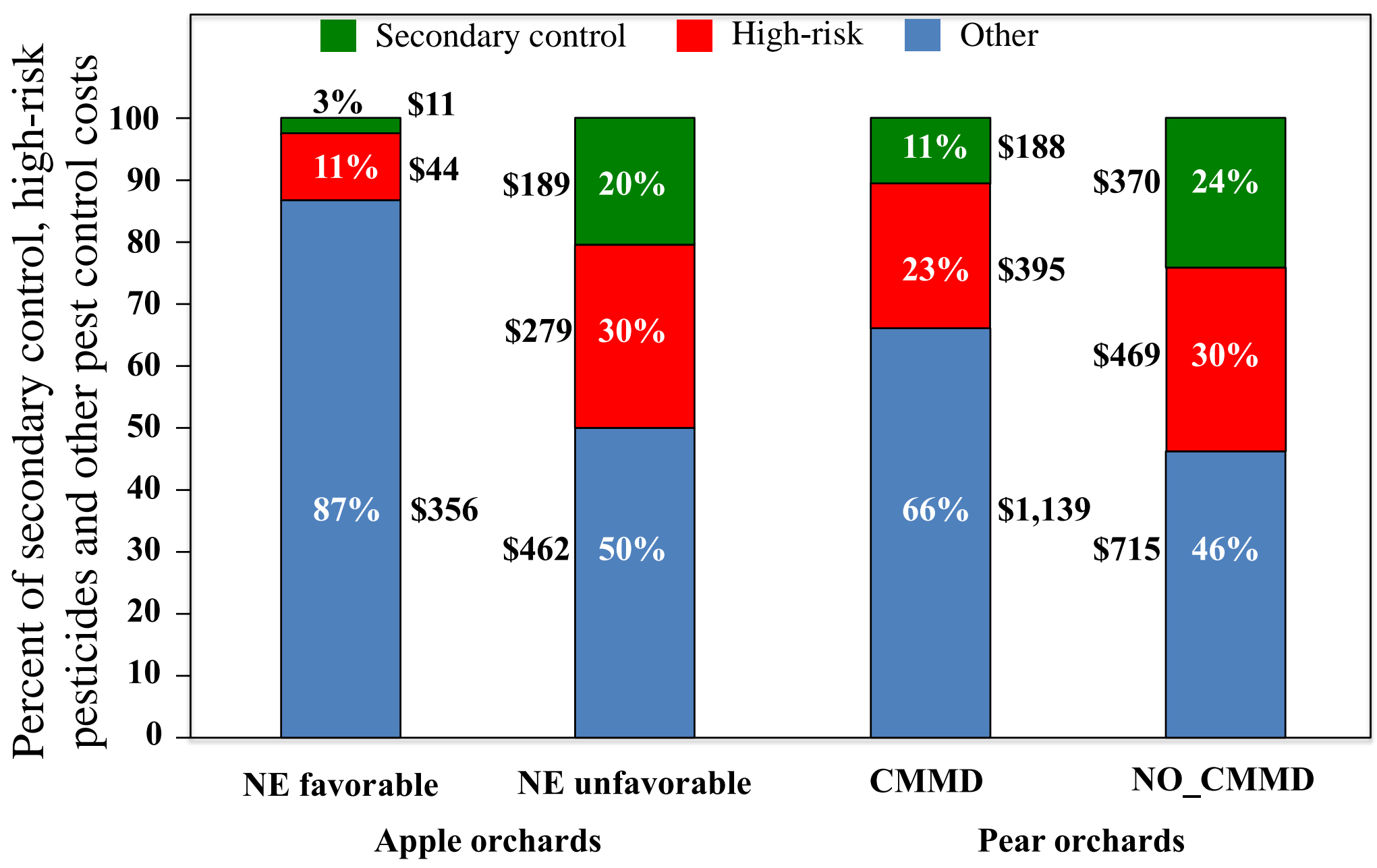


Fig. 1.

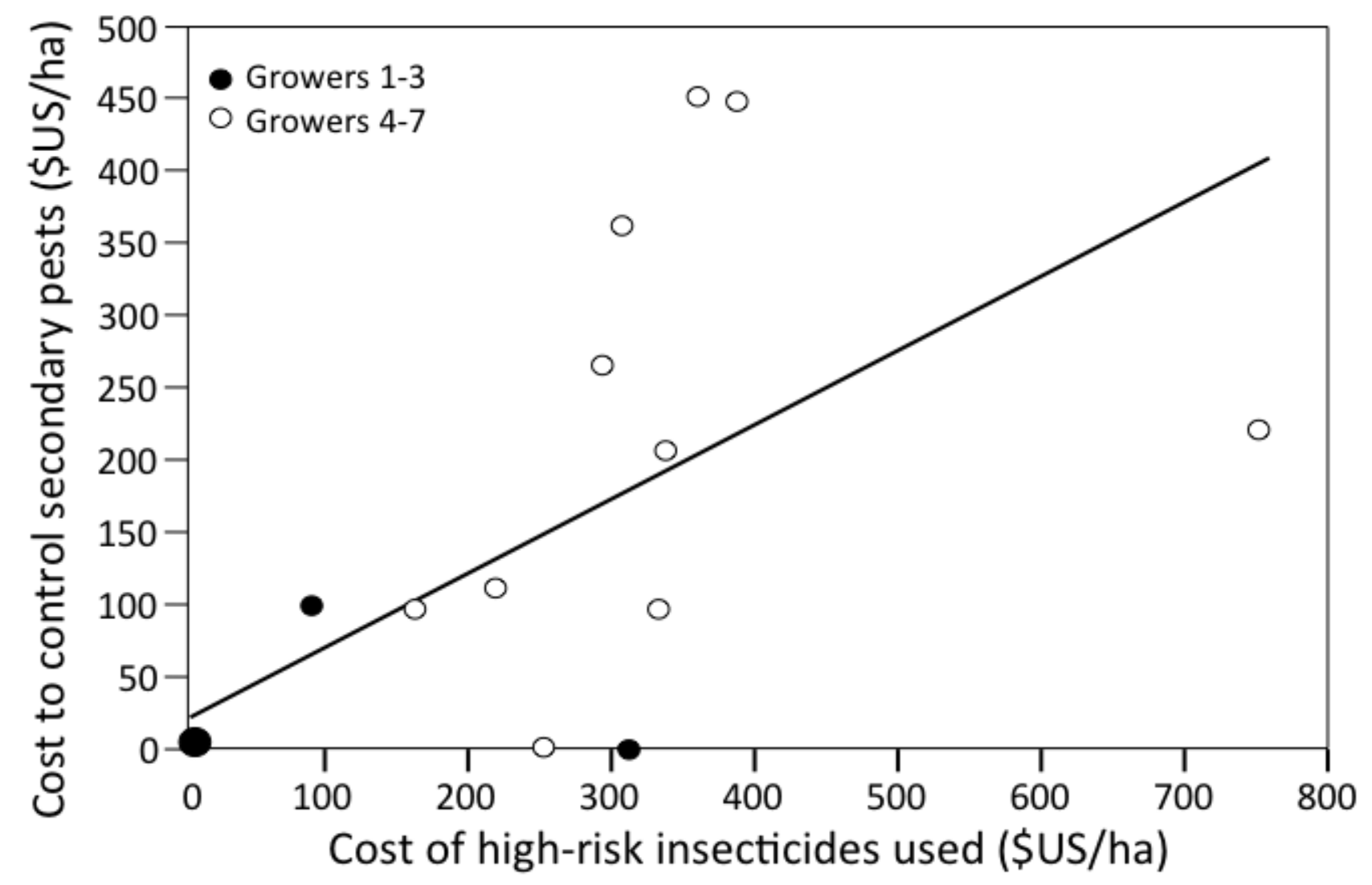


Fig. 2A, B.

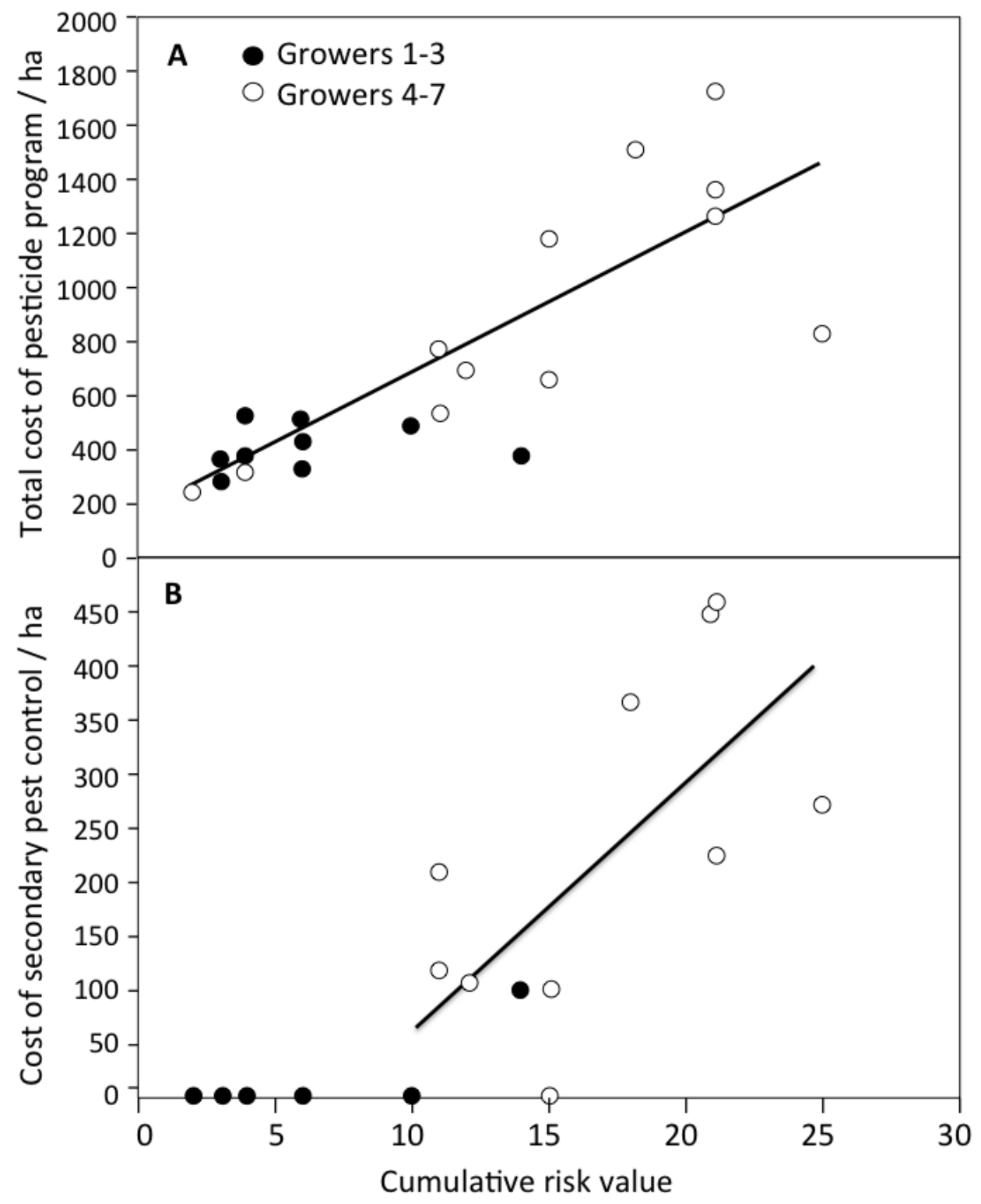


Fig. 3.

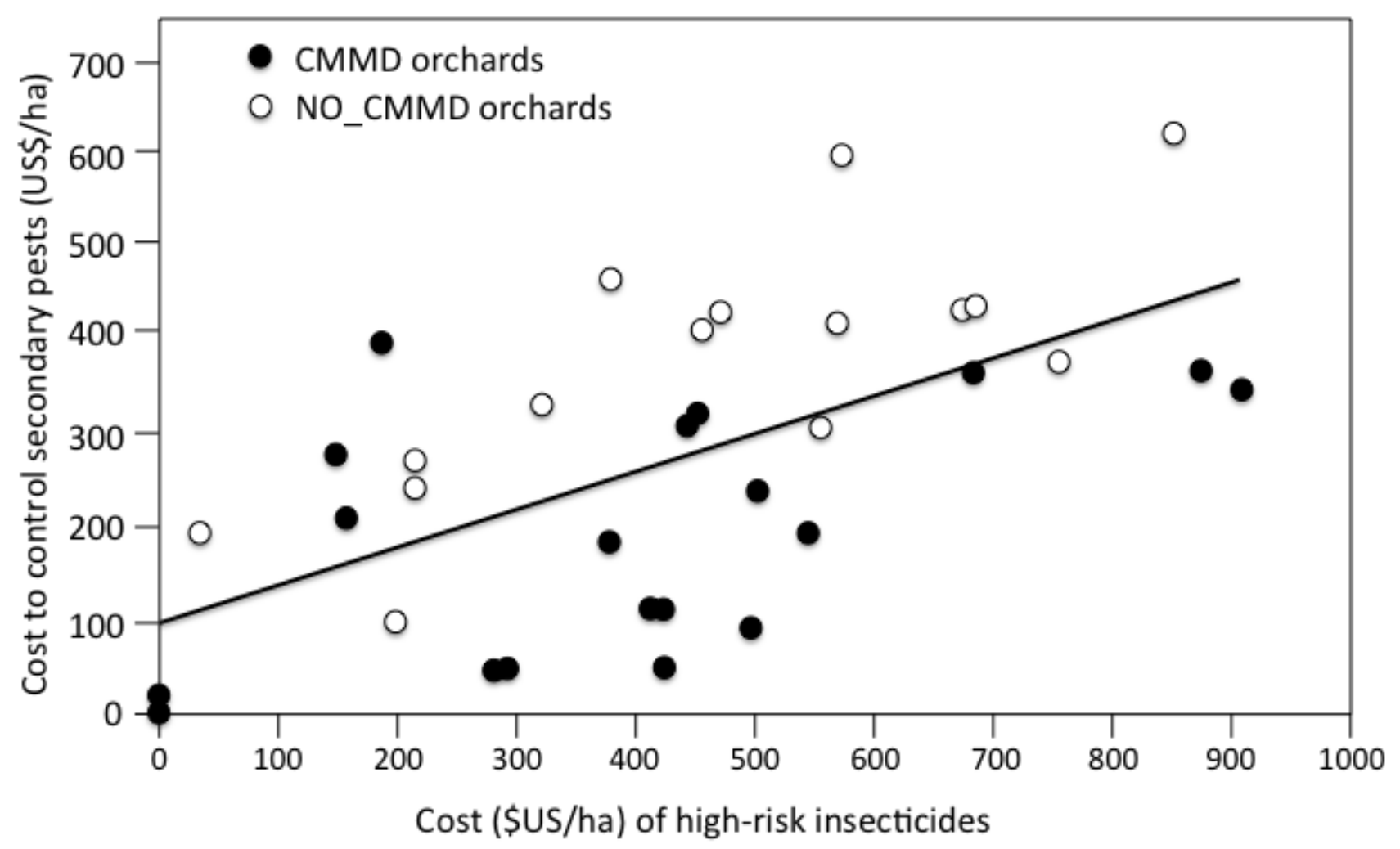


Fig. 4A, B

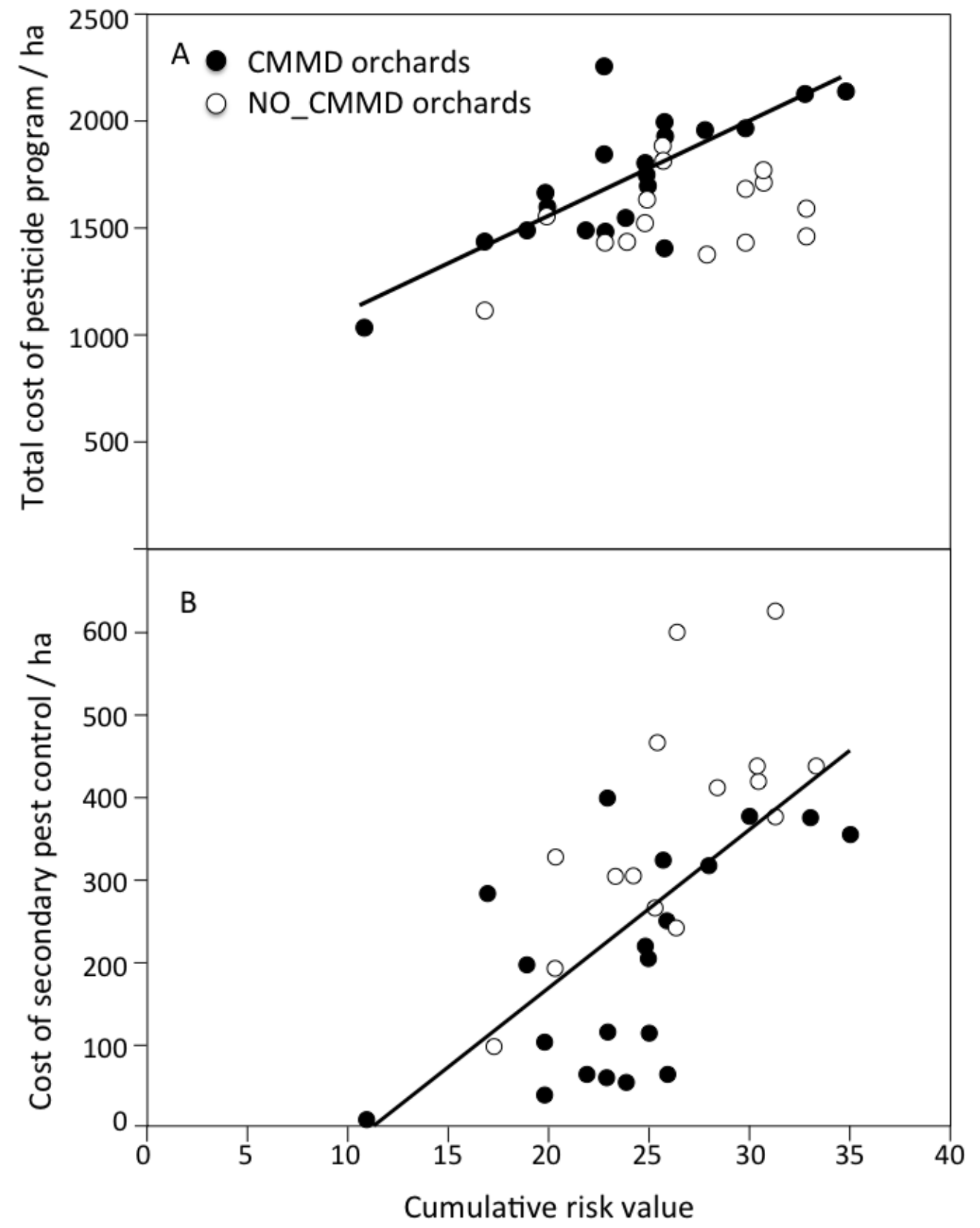

